\title{
Factors affecting receipt of chemotherapy in women with breast cancer
}

\author{
This article was published in the following Dove Press journal: \\ International Journal of Women's Health \\ 4 May 2010 \\ Number of times this article has been viewed
}

\section{Libby Morimoto' \\ Jenna Coalson' \\ Fionna Mowat ${ }^{\prime}$ \\ Cynthia O’Malley²}

'Exponent Health Sciences, Menlo Park, CA, USA; ${ }^{2}$ Amgen Global Epidemiology, Thousand Oaks, CA, USA
Correspondence: Cynthia O'Malley

One Amgen Center Drive, MS 24-2-A,

Thousand Oaks, CA 91320-1799, USA

$\mathrm{Tel}+\mathrm{I} 8053$ 3 3634 I

Fax +I 805447 I984

Email comalley@amgen.com
Aims: To review literature describing factors associated with receipt of chemotherapy for breast cancer, to better understand what factors are most relevant to women's health and whether health disparities are apparent, and to assess how these factors might affect observational studies and outcomes research. Patterns of care for metastatic breast cancer, for which no standard-of-care exists, were of particular interest.

Methods: Relevant studies written in English, Italian, French, or Spanish, published in 2000 or later, were identified through MEDLINE and reviewed. Review articles and clinical trials were excluded; all observational studies and surveys were considered. Articles were reviewed for any discussion of patient characteristics, hospital/physician/insurance characteristics, psychosocial characteristics, and clinical characteristics affecting receipt of chemotherapy by breast cancer patients.

Results: In general, factors associated with increased likelihood of receiving chemotherapy included younger age, being Caucasian, having good general health and few co-morbidities, having more severe clinical disease, having responded well to previous treatment, and having breast cancer that is estrogen- or progesterone-receptor-negative. Many of the clinical factors found to increase the likelihood of receiving chemotherapy were consistent with current oncology guidelines. Of the relevant 19 studies identified, only six (32\%) reported data specific to metastatic cancer; most studies aggregated women with stage I-IV for purposes of analysis.

Conclusion: Studies of patterns of care in breast cancer treatment can help identify challenges in health care provided to particular subgroups of women and can aid researchers in designing studies that account for such factors in clinical and outcomes research. Although scarce, studies evaluating only women with metastatic breast cancer indicate that factors affecting decisions related to receipt of chemotherapy are similar across stage for this disease.

Keywords: breast cancer, chemotherapy, metastatic, treatment decisions, health disparities

\section{Introduction}

As the most common cancer affecting American women, significant research effort and resources have been dedicated to the prevention, control, and treatment of breast cancer. Since 2003, breast cancer research accounts for the highest proportion of appropriated National Cancer Institute (NCI) funds for an individual cancer. ${ }^{1}$ Despite these efforts, however, breast cancer remains a poorly understood disease and a significant cause of morbidity and mortality among American women. For the estimated 192,000 American women who will develop breast cancer in $2009,{ }^{2}$ factors affecting their prognosis and survival from disease are of utmost importance. Therefore, the need continues for breast cancer research and public health education and outreach programs. 
Observational studies play an important role in studies of treatment effectiveness and survival, and can play a role in optimizing the use of therapeutics. Compared to clinical trials, they are able to quantify rarer events over longer periods of time and can provide a "real-world" picture of drug efficacy and safety in actual usage outside the trial setting. However, observational studies, like other research formats, are susceptible to potential biases from misclassification, differential selection, confounding, and incomplete adherence. Studies examining patterns of care in cancer treatment, therefore, provide valuable information for researchers that can affect the outcome and interpretation of results.

For breast cancer, late-stage and metastatic breast cancer treatment patterns are particularly difficult to study. Although only $6 \%$ of patients have metastatic/stage IV disease at diagnosis, ${ }^{3} 10 \%$ to $40 \%$ of women with early-stage breast cancer will eventually develop distant disease and metastases. ${ }^{4,5}$ For these women, there is no standard-of-care guideline, and complex treatment decisions are based on individual patient and tumor characteristics. The goal is generally to manage symptoms and prolong life, rather than to cure the disease. Recommended treatment for incident or recurrent stage IV breast cancer may include surgery, hormone therapy, aromatase inhibitors, ovarian ablation or suppression, therapeutic or palliative chemotherapy, or supportive care, depending on the patient's prior treatments (radiation, surgery, antiestrogens, previous chemotherapy), tumor hormone receptor status, physical health, and menopausal status. ${ }^{6}$ For many of these, decisions are made primarily on the basis of clinical status, as is called for in typical oncology guidelines. Patients' preferences for treatment have become increasingly important in clinical decision making, and factors such as trade-offs between quantity and quality of life, and patient hopes, expectations, values, and priorities, are weighed. ${ }^{7}$ With each progressive step of planning a patient's care, numerous selection factors are introduced that can affect receipt of treatment.

In addition to patient preferences, some factors beyond a patient's control can dictate whether they are treated with chemotherapy for late-stage disease. Health disparities in cancer outcomes and treatment have been well documented, and addressing the causes and establishing measures to mitigate these differences have become increasingly higher priorities of government health care program policies. ${ }^{8-10}$ Cancer health disparities, frequently marked by age, race/ethnicity, income, educational attainment, or geographic location, ${ }^{9}$ are reflected in differences in cancer incidence, mortality, and survival rates across groups and are thought to be due to disparities in access to health care, which affects screening rates, treatment resources, and the quality of treatment given. ${ }^{11}$ Therefore, the decision to treat with chemotherapy for breast cancer may also be influenced by a woman's inability to receive treatment if desired, as well as by lack of knowledge about the treatment options available to her.

Factors affecting the receipt of chemotherapy in women with breast cancer have been well studied, but no literature currently exists that compiles factors associated with patient characteristics, hospital/physician/insurance characteristics, psychosocial characteristics, and clinical characteristics in a single source. For example, it is commonly understood that older women are generally less likely to receive chemotherapy due to the shorter life expectancies of older women, general poorer health, and the reduced risk/benefit; however, other factors may also influence receipt of chemotherapy, even in younger women, and need to be accounted for in observational studies and outcomes research involving breast cancer. In addition, quantifiable information on specific influences of palliative treatment of metastatic breast cancer is particularly scarce. Therefore, we performed a review of the literature and information published since 2000 regarding the factors affecting decision making for the receipt of chemotherapy in patients with breast cancer, particularly metastatic cancer, taking into account patient characteristics, hospital/physician/insurance characteristics, psychosocial characteristics, and clinical characteristics.

\section{Methods}

\section{Literature search and review}

A MEDLINE search was performed using the following query: $<<$ breast cancer AND (recurrent OR metastatic OR advanced stage OR advanced disease OR stage IV OR stage I OR stage II or stage II or early stage OR early disease) AND (chemotherapy OR treatment OR second line OR third line) AND (practice patterns OR health services OR decision-making OR predictors OR disparity OR correlates OR quality of life) NOT ("review" [Publication Type]) NOT ("clinical trial" [Publication Type]) NOT ("case reports" [Publication Type]) $>>$. Searches were limited to the year 2000 or later. Review articles, case reports, and clinical trials were excluded; observational, clinical, and population-based studies were considered, as were survey data of physicians and oncologists. General clinical reviews that provided treatment guidelines but no original data were also excluded. This initial search returned 491 studies discussing chemotherapy and breast cancer, of which 46 were deemed relevant for further review based on criteria that were set a priori by the 
contributing authors and as containing information related to the four categories of interest (patient characteristics, hospital/ physician/insurance characteristics, psychosocial characteristics, and clinical characteristics). The bibliographies of these studies, as well as those of several recent review articles, were also reviewed, and an additional 35 articles of potential relevance were identified. All articles were reviewed by one or more authors; studies were excluded from our discussion if they specifically excluded cases of metastatic breast cancer, if they did not include information regarding chemotherapy as a treatment, or if they contained only data on the differences in response to (not receipt of) chemotherapy. Thus, articles identified spanned receipt of chemotherapy treatment in stage I-IV breast cancer patients.

Using the above criteria, of the 81 articles reviewed, 19 were identified as pertinent to treatment decision-making in breast cancer (either specific to or including stage IV) and chemotherapy, ${ }^{12-30}$ and 62 were excluded. Of the 19 studies, only six provided data specific to metastatic (stage IV) disease. ${ }^{13,18,19,21-23}$ One of these ${ }^{22}$ reported tabular data for "metastatic" breast cancer, but discussed the cases as "advanced" breast cancer in the text. For the purposes of this paper, we considered the data to be specific to metastatic disease. Most of the studies were conducted in populations in the United States ${ }^{12,15,17,18,23-29}$ and the United Kingdom. ${ }^{16,20,22,30}$ Studies from other countries included one from France ${ }^{19}$ and one from Australia. ${ }^{13}$

The factors studied in relation to receipt of chemotherapy were roughly divided into four primary categories: patient characteristics, hospital/physician/insurance characteristics, psychosocial characteristics, and clinical characteristics. Some studies spanned more than one factor. Of the 19 studies identified as relevant, 15 mentioned patient characteristics, including demographic characteristics such as age, race, marital status, socioeconomic status (SES), and education. Four mentioned hospital/physician/insurance characteristics such as insurance status, physician type, and type of medical facility, while five mentioned psychosocial characteristics, including patient anxiety and depression. Finally, seven studies mentioned clinical characteristics such as tumor markers, lymph-node involvement, type of previous treatment, response to previous treatment, patient general health, and the presence of co-morbidities. Our findings for each factor are summarized individually in the following sections.

\section{Results}

\section{Patient characteristics}

Patient characteristics evaluated in the studies identified included age, race, SES/income, education, and language barriers (Table 1). Age was the most frequently considered characteristic, being discussed in 10 studies. ${ }^{14,15,17-20,22,26,28,30}$ Race was considered in five studies, ${ }^{12,18,25,26,29} \mathrm{SES} /$ income in three, ${ }^{12,16,24}$ education in four, ${ }^{12,22,26,28}$ and language barriers in two. ${ }^{12,22}$

\section{Age}

All of the studies identified found that older women received chemotherapy less commonly than did younger women. ${ }^{14,15,17-20,26,28,30}$ Of these studies, seven provided numerical data to support this conclusion (Table 1). ${ }^{15,17-20,28,30}$ Five of the studies demonstrated a statistically significant difference in chemotherapy use between older and younger women, ${ }^{17-20,28}$ although only two of these provided data specific to metastatic breast cancer. ${ }^{18,19}$ In a prospective survey of qualified specialists in France, the authors noted that, of the women receiving chemotherapy, $82 \%$ in the younger age group received the standard dose and cycle length, but only $62 \%$ of those in the older age group received it $(P<0.01) .{ }^{19}$ Odds ratios (ORs) were presented from the Surveillance Epidemiology and End Results (SEER)-Medicare-linked database of women with breast cancer diagnosed in 1991 and 1992, where the odds of receiving chemotherapy among US women with Medicare claims decreased with increasing age as 0.60 (95\% confidence interval [CI]: $0.51-0.70), 0.33(95 \%$ CI: 0.27-0.40), and 0.11 (95\% CI: 0.0-0.14) for women aged 70-74, 75-79, and 80 years and older, respectively, relative to women aged 65-69 years. Among women with stage IV disease, the proportion with Medicare claims for chemotherapy decreased from 39\% among women between the ages of 65 and 69 years to only $10 \%$ among women 80 years of age or older. ${ }^{18}$ In a survey administered to medical and clinical oncologists in the UK, asking which factors were important in deciding whether to recommend chemotherapy to patients with metastatic breast cancer, patient age was considered to be "quite important" or "very important" for $58.6 \%$ of oncologists surveyed. ${ }^{22}$

Several studies offered reasons to explain why older women received chemotherapy less often. Commonly cited reasons included little clinical evidence to prove the benefit of chemotherapy in older women, ${ }^{30}$ the shorter life expectancies of older women and the reduced cost/ benefit, ${ }^{28-31}$ and having fewer incentives (eg, dependents) to invest in therapies that may extend their lives. ${ }^{28}$ The lower proportion of older women with breast cancer receiving chemotherapy may also reflect an increased number of co-morbidities and worse general health among these women. ${ }^{19}$ For example, among British oncologists, "frailty" 
Table I Studies related to the role of patient characteristics in treatment decision making for breast cancer

\begin{tabular}{|c|c|c|c|c|}
\hline Reference & $\begin{array}{l}\text { Number of } \\
\text { subjects in study }\end{array}$ & $\begin{array}{l}\text { Percent of patients } \\
\text { receiving chemotherapy }\end{array}$ & Odds ratio & Comment \\
\hline \multicolumn{5}{|l|}{ Age } \\
\hline Caban et $\mathrm{al}^{14}$ & $\mathrm{n}=234$ & $\begin{array}{l}\text { Patient age was a } \\
\text { significant predictor } \\
\text { of neoadjuvant therapy }\end{array}$ & - & $\begin{array}{l}\text { Data not shown } \\
\text { Study included stages I-IV }\end{array}$ \\
\hline Diab et al ${ }^{15}$ & $\begin{array}{l}\mathrm{n}=50,828 \text { (San Antonio } \\
\text { breast cancer databases) } \\
\mathrm{n}=256,287 \text { (SEER) }\end{array}$ & $\begin{array}{l}\text { 55-64 years: } 30 \\
65-74 \text { years: } 16 \\
75-84 \text { years: } 6 \\
\geq 85 \text { years: I }\end{array}$ & - & Study included stages I-IV \\
\hline \multirow[t]{2}{*}{ Goodwin ${ }^{17}$} & $\begin{array}{l}n=10,604 \\
-65-69: n=2,893 \\
-70-74: n=2,901 \\
-75-79: n=2,280 \\
-\geq 80: n=2,530\end{array}$ & $\begin{array}{l}65-69 \text { years: } 39 \\
\geq 80 \text { years: } 10\end{array}$ & - & $\begin{array}{l}\text { Information is specific } \\
\text { to stage IV disease }\end{array}$ \\
\hline & & - & $\begin{array}{l}\text { Odds of receiving } \\
\text { chemotherapy relative to } \\
65-69 \text { year olds: } \\
70-74 \text { years: } 0.60 \\
(95 \% \text { Cl: } 0.5 \mathrm{I}-0.70) \\
75-79 \text { years: } 0.33 \\
(95 \% \text { Cl: } 0.27-0.40) \\
\geq 80 \text { years: } 0.1 \text { I } \\
(95 \% \mathrm{Cl}: 0.08-0.14)\end{array}$ & $\begin{array}{l}\text { Information includes stages } \\
\text { I-IV }\end{array}$ \\
\hline $\begin{array}{l}\text { Du and } \\
\text { Goodwin }\end{array}$ & $\begin{array}{l}\mathrm{n}=35,060 \\
\text { (no age-specific n's given) }\end{array}$ & $\begin{array}{l}65-69 \text { years: } 21 \\
70-74 \text { years: } 14 \\
75-79 \text { years: } 9 \\
80+\text { years: } 3\end{array}$ & $\begin{array}{l}\text { Odds of receiving } \\
\text { chemotherapy relative to } \\
65-69 \text { year olds: } \\
70-74 \text { years: } 0.55 \\
(95 \% \text { Cl: } 0.50-0.60) \\
75-79 \text { years: } 0.29 \\
(95 \% \text { Cl: } 0.26-0.32) \\
80+\text { years: } 0.08 \\
(95 \% \mathrm{Cl}: 0.07-0.09)\end{array}$ & Study included stages I-IV \\
\hline \multirow[t]{2}{*}{ Freyer et al ${ }^{19}$} & $\begin{array}{l}n=1,009 \\
-65-74: n=500 \\
-\geq 75: n=509\end{array}$ & $\begin{array}{l}65-74 \text { years: } 50 \\
\geq 75 \text { years: } 28\end{array}$ & - & $\begin{array}{l}\text { Study included only stage IV } \\
\text { cases } \\
\text { Reported } P \text {-value }<0.00 \text { I }\end{array}$ \\
\hline & & $\begin{array}{l}\text { Percentages receiving the } \\
\text { standard dose and } \\
\text { cycle length: } \\
65-74 \text { years: } 82 \\
\geq 75 \text { years: } 62\end{array}$ & - & $\begin{array}{l}\text { Study included only stage IV } \\
\text { cases } \\
\text { Reported } P \text {-value }<0.0 \text { I }\end{array}$ \\
\hline \multirow[t]{2}{*}{ Golledge et $\mathrm{a}^{20}$} & $\begin{array}{l}n=784 \\
-<50: n=181 \\
-50-59: n=171 \\
-60-69: n=179 \\
-70-79: n=143 \\
-\geq 80: n=110\end{array}$ & $\begin{array}{l}\text { Lymph node positive } \\
\text { cases: } \\
<50 \text { years: } 58 \\
\text { 50-59 years: } 36 \\
60-69 \text { years: } 11 \\
70-79 \text { years: } 3 \\
\geq 80 \text { years: } 6\end{array}$ & - & - \\
\hline & & $\begin{array}{l}\text { Lymph node negative } \\
\text { cases: } \\
<50 \text { years: } 30 \\
50-59 \text { years: } 7 \\
60-69 \text { years: I } \\
70-79 \text { years: I } \\
\geq 80 \text { years: } 0\end{array}$ & - & $\begin{array}{l}P \text {-value compares the age } \\
\text { groups }<60 \text { years and } \\
\geq 60 \text { years } \\
\text { Reported } P \text {-value }<0.000 \text { I } \\
\text { Study includes stages I-IV }\end{array}$ \\
\hline
\end{tabular}


Table I (Continued)

\begin{tabular}{|c|c|c|c|c|}
\hline Reference & $\begin{array}{l}\text { Number of } \\
\text { subjects in study }\end{array}$ & $\begin{array}{l}\text { Percent of patients } \\
\text { receiving chemotherapy }\end{array}$ & Odds ratio & Comment \\
\hline Grunfeld et $\mathrm{al}^{22}$ & $\mathrm{n}=30$ oncologists & - & - & $\begin{array}{l}\text { Surveyed for stage IV } \\
\text { treatment only } \\
\text { Authors reported that } \\
58.6 \% \text { of clinicians rated age } \\
\text { as quite or very important } \\
\text { in decision to give pallitive } \\
\text { chemotherapy }\end{array}$ \\
\hline Mitchell et $\mathrm{al}^{26}$ & $\mathrm{n}=682$ & $\begin{array}{l}\text { Older age was a } \\
\text { significant predictor } \\
\text { of belief in religious } \\
\text { intervention in place } \\
\text { of treatment }\left(r^{2}=0.1 \mathrm{I}\right)\end{array}$ & - & $\begin{array}{l}\text { Study interviewed } \\
\text { cancer-free women about } \\
\text { hypothetical breast cancer } \\
\text { experiences } \\
\text { Reported } P \text {-value }<0.000 \text { I }\end{array}$ \\
\hline Peele et $\mathrm{a}^{28}$ & $\mathrm{n}=386$ & $\begin{array}{l}\text { Younger patients were } \\
\text { more likely to choose } \\
\text { adjuvant therapy }\end{array}$ & - & $\begin{array}{l}\text { Study included stages I-IV } \\
\text { Reported } P \text {-value of } 0.006\end{array}$ \\
\hline Wyld et a ${ }^{30}$ & $\begin{array}{l}\mathrm{n}=378 \\
\text { Age group } \\
-55-69: \mathrm{n}=210 \\
-\geq 70: \mathrm{n}=167\end{array}$ & $\begin{array}{l}55-69 \text { years: } 32.0 \\
\geq 70 \text { years: } 0.01\end{array}$ & - & Study included stages I-IV \\
\hline Race & & & & \\
\hline $\begin{array}{l}\text { Ashing-Giwa } \\
\text { et al }{ }^{12}\end{array}$ & $\begin{array}{l}\mathrm{n}=102 \\
\text { - African-American: } \mathrm{n}=24 \\
\text { - Asian: } \mathrm{n}=34 \\
\text { - Latina: } \mathrm{n}=26 \\
\text { - Caucasian: } \mathrm{n}=18\end{array}$ & $\begin{array}{l}\text { African Americans } \\
\text { were the least likely } \\
\text { to have received } \\
\text { adjuvant therapies, } \\
\text { including chemotherapy }\end{array}$ & - & $\begin{array}{l}\text { Data not shown } \\
\text { Interviews with cases } \\
\text { in stages I-IV }\end{array}$ \\
\hline $\begin{array}{l}\text { Du and } \\
\text { Goodwin } 17\end{array}$ & $\begin{array}{l}\mathrm{n}=10,604 \\
\text {-White: } \mathrm{n}=9,754 \\
\text { - Black: } \mathrm{n}=540 \\
\text { - Other: } \mathrm{n}=310\end{array}$ & $\begin{array}{l}\text { White: } 26.5 \\
\text { Black: } 26.8 \\
\text { Other: } 18.2\end{array}$ & - & $\begin{array}{l}\text { Information is specific to } \\
\text { stage IV disease }\end{array}$ \\
\hline & & - & $\begin{array}{l}\text { Odds of receiving } \\
\text { chemotherapy relative } \\
\text { to white patients: } \\
\text { Black: } 0.93 \text { ( } 95 \% \mathrm{Cl}: 0.70-1.23) \\
\text { Other: } 0.66 \text { ( } 95 \% \mathrm{Cl}: 0.43-1.10)\end{array}$ & $\begin{array}{l}\text { Information includes stages } \\
\text { I-IV }\end{array}$ \\
\hline Maloney et $\mathrm{a}^{25}$ & $\begin{array}{l}\mathrm{n}=52 \\
\text { - African-American: } \mathrm{n}=36 \\
\text { - Caucasian: } \mathrm{n}=16\end{array}$ & $\begin{array}{l}\text { Caucasian: } 81.3 \\
\text { African American: } 80.0\end{array}$ & - & $\begin{array}{l}\text { Study included stages I-IV } \\
\text { Reported } P \text {-value } 0.92\end{array}$ \\
\hline Mitchell et $\mathrm{a}^{26}$ & $\begin{array}{l}n=682 \\
\text { - African-American: } n=280 \\
\text { - White: } n=402\end{array}$ & $\begin{array}{l}\text { Being African American } \\
\text { was a significant predictor } \\
\text { of belief in religious } \\
\text { intervention in place } \\
\text { of treatment }\left(r^{2}=0.4 \mathrm{I}\right)\end{array}$ & - & $\begin{array}{l}\text { Study interviewed } \\
\text { cancer-free women about } \\
\text { hypothetical breast cancer } \\
\text { experiences } \\
\text { Reported } P \text {-value }<0.00 \text { I }\end{array}$ \\
\hline Shavers et $\mathrm{al}^{29}$ & $\begin{array}{l}\mathrm{n}=3,978 \\
\text { - African-American: } \mathrm{n}=724 \\
\text { - Hispanic: } \mathrm{n}=616 \\
\text { - Non-Hispanic white: } \mathrm{n}=2,638\end{array}$ & $\begin{array}{l}\text { African American: } 46.5 \\
\text { Hispanic: } 52.4 \\
\text { Non-Hispanic white: } 67.0\end{array}$ & - & Study included stages I-IV \\
\hline \multicolumn{5}{|l|}{ SES/Income } \\
\hline Ashing-Giwa et al ${ }^{12}$ & $\mathrm{n}=102$ & - & - & $\begin{array}{l}\text { Interviews with cases in } \\
\text { stages I-IV } \\
\text { Authors observed that } \\
\text { women with lower SES lack } \\
\text { awareness regarding the } \\
\text { disease, resources, and treat- } \\
\text { ments, and are not proactive } \\
\text { about seeking medical care }\end{array}$ \\
\hline
\end{tabular}

(Continued) 
Table I (Continued)

$\begin{array}{lll}\begin{array}{l}\text { Percent of patients } \\ \text { receiving chemotherapy }\end{array} & \text { Odds ratio } & \text { Comment }\end{array}$

\begin{tabular}{ll}
\hline Reference & $\begin{array}{l}\text { Number of } \\
\text { subjects in study }\end{array}$ \\
\hline${\text { Downing et } \text { al }^{16}}^{\mathrm{n}}=\mid \mathrm{I} 2,768$ \\
& \\
Liu et al & \\
& WHN: $\mathrm{n}=33 \mathrm{I}$ (lower income) \\
& Other in MA state: \\
Education & $\mathrm{n}=\mid 3,372$ \\
Ashing-Giwa et al $^{12}$ & $\mathrm{n}=102$
\end{tabular}

Quartile II: 28.7

Quartile IV (deprived): 26.4

Lower income: 35.4

Overall: 37.2

$-$

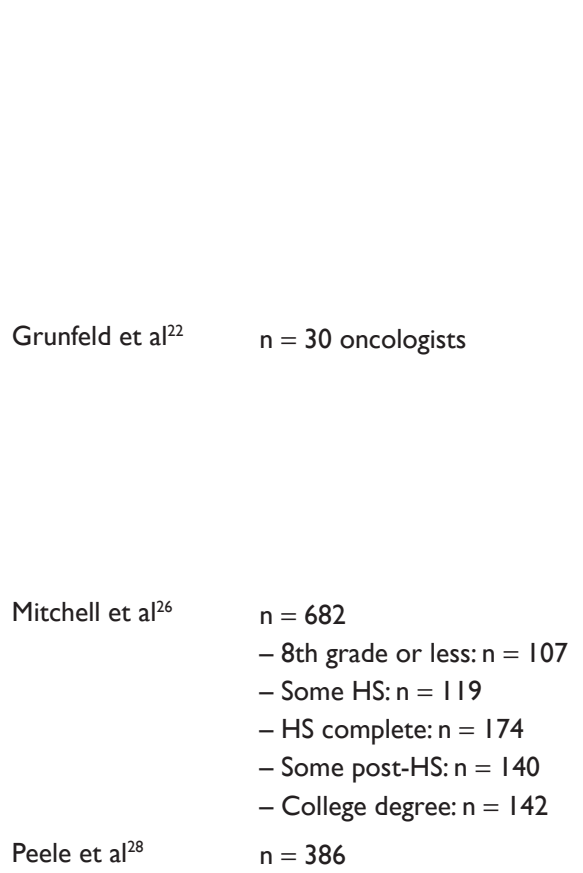

Peele et al $^{28} \quad \mathrm{n}=386$

\section{Language barriers}

Ashing-Giwa et al ${ }^{12} \quad \mathrm{n}=102$ a significant predictor of

belief in religious

intervention in place of

treatment $\left(r^{2}=-0.19\right)$

Women with more years

of education were more

likely to receive

chemotherapy
Having less education was _-
Grunfeld et $\mathrm{al}^{22} \quad \mathrm{n}=30$ oncologists

Study included stages I-IV

Authors reported that

results were "not significant"

Study included stages I-IV

Numbers also reported

under Insurance Status

Interviews with cases in

stages I-IV

Authors observed that

women with less education

lack awareness regarding

the disease, resources, and

treatments, and are not as

proactive about seeking

medical care

Surveyed for stage IV

treatment only

Authors reported that $13.8 \%$

of clinicians rated education

level as quite or very

important in decision to give

palliative chemotherapy

Study interviewed

cancer-free women about

hypothetical breast cancer

experience

Reported $P$-value $<0.000$ I

Study included stages I-IV

Reported $P$-value of 0.006

Interviews with cases in stages I-IV Authors reported that language barriers prevented half of the Latinas and some of the monolingual Asian-Americans in their study from following and meeting the requirements for treatment-related financial assistance

Surveyed for stage IV treatment only Authors reported that $20.7 \%$ of clinicians rated language barriers as quite or very important in decision to give palliative chemotherapy

Abbreviations: OR, odds ratio; Cl, confidence interval; NR, not reported; BCS, breast-conserving surgery; SES, socioeconomic status; WHN,Women's Health Network; HS, high school; MA, Massachusetts. 
and "concurrent medical conditions" were deemed "quite important" or "very important" to $93.1 \%$ and $82.8 \%$ of surveyed clinicians, respectively, compared to the $58.6 \%$ of oncologists who considered age to be of importance. ${ }^{22}$ Of the 10 studies in this review citing the impact of age on chemotherapy use, only two adjusted for co-morbidities, ${ }^{17,18}$ one of which ${ }^{18}$ provided data specific to metastatic breast cancer. In both studies, multivariate analyses revealed a stronger inverse association of increasing age and chemotherapy use than that of co-morbidity and chemotherapy use. The higher prevalence of hormone receptor (estrogen-or progesteronereceptor $[\mathrm{ER} / \mathrm{PR}]$ ) positive tumors among postmenopausal women than premenopausal women, ${ }^{32}$ and therefore more frequent use of hormone therapy, also contributes to this observation. It has been suggested that elderly patients have cancers with lower proliferative indices, and that they will derive less benefit from standard chemotherapy; ${ }^{33}$ however, the elderly are frequently underrepresented in cancer clinical trials. Although elderly (65 years of age or older) patients make up $63 \%$ of cancer patients in the US, they represent only $25 \%$ of the cancer clinical trial participants. ${ }^{34}$ Whether this deficit is due to fear and misunderstanding of older patients, physician bias against enrolling older patients, or overly stringent eligibility criteria that limit the number of elderly patients, their underrepresentation makes it difficult to assess the risks and benefits of cancer chemotherapeutic regimens and may partially explain the inverse relationship between age and chemotherapy use.

\section{Race}

Five studies, all conducted in the United States, considered race to be a factor in predicting receipt of chemotherapy in breast cancer patients ${ }^{12,18,25,26,29}$ Only one study presented data specific to metastatic breast cancer, ${ }^{18}$ with the remainder considering all cases (stages I through IV) in aggregate. In $\mathrm{Du}$ and Goodwin, ${ }^{18}$ the proportions of black and white women with stage IV breast cancer who received chemotherapy were similar (26.8\% versus $26.5 \%$, respectively), although fewer women whose race was classified as "other" received chemotherapy (18.2\%). Two other studies (not specific to stage IV disease) reported very small differences in the percentages of Caucasian, African-American, and Hispanic women with breast cancer treated with chemotherapy; both noted that higher proportions of Caucasian women $\left(81.3 \%{ }^{25}\right.$ and $\left.67.0 \%{ }^{29}\right)$ than African-American women $\left(80.0 \%{ }^{25}\right.$ and $\left.46.5 \%{ }^{29}\right)$ or Hispanic women $\left(52.4 \%{ }^{29}\right)$ received chemotherapy, although these differences either were not statistically significant ${ }^{25}$ or statistical significance was not evaluated. ${ }^{29}$
A qualitative study interviewed women of different races and indicated that African-American women were the least likely to receive adjuvant therapies, including chemotherapy, and it was suggested that economic-related issues and insufficient insurance coverage might be the underlying reasons. ${ }^{12}$ Two studies reported that African-American women were more likely to believe in alternative medicine or religious intervention in place of Western treatments. ${ }^{12,26}$ Only one study reported on Hispanic women. Similar to the age effect, the disparities in cancer care among ethnic minorities have been well documented in the literature..$^{9,12,13,15}$ Treatment for ethnic minority groups may also be influenced by other factors that affect these groups, including socioeconomic issues, cultural beliefs, language barriers, challenges in access to care, and different rates of co-morbidities, ${ }^{35}$ making it difficult to determine the optimal method to address this disparity.

\section{SES/Income}

Three studies discussed SES or income in relation to chemotherapy treatment - two in the US ${ }^{12-24}$ and one in the $\mathrm{UK}^{16}$ - although none was specific to metastatic breast cancer. Of the two studies that provided numerical data, neither observed a significant difference in the proportions of patients receiving chemotherapy by income or SES, ${ }^{16-24}$ although one suggested that their observation that uninsured, lower income women were less likely to receive chemotherapy may have reached statistical significance with a larger sample size. ${ }^{24}$ A qualitative study of community health professionals working with diverse populations reported that individuals with lower SES may lack awareness regarding the disease, resources, and treatments, and are not as proactive about seeking medical care. ${ }^{12}$

\section{Education}

Four studies discussed education level in relation to chemotherapy treatment, ${ }^{12,22,26,28}$ as well as other adjuvant therapies such as radiation and hormone therapy; only two provided quantitative data related to chemotherapy, ${ }^{26-28}$ and only one was specific to metastatic breast cancer. ${ }^{22}$ Peele and colleagues stated that educated women were significantly more likely to choose treatment with adjuvant therapy, including chemotherapy, hormone therapy, and combination therapy, although the study did not distinguish between cases based on disease severity and treatment. ${ }^{28}$ Mitchell and colleagues reported that having less education was statistically significantly $(P<0.0001)$ and inversely correlated with a belief in "religious intervention in place of treatment"; 26 it is presumed that the treatment likely included chemotherapy due to inclusion 
of women with advanced-stage breast cancer in the study population. Qualitatively, Ashing-Giwa and colleagues, when discussing various adjuvant therapies, including chemotherapy, reported that less-educated women in the United States were less informed about breast cancer itself, as well as resources and treatments, and were less proactive in seeking medical care. ${ }^{12}$ In the UK, $13.8 \%$ of clinicians ranked education as an important factor influencing their recommendation for palliative chemotherapy to women with metastatic breast cancer. ${ }^{22}$

\section{Language barriers}

Only two studies, both qualitative, discussed the effect of language barriers on the receipt of chemotherapy. ${ }^{12,22}$ Ashing-Giwa and colleagues reported that language barriers prevented half of the Latinas and some of the monolingual Asian-Americans in their study from following and meeting the requirements for treatment-related financial assistance, ${ }^{12}$ while Grunfeld and colleagues reported that only $20.7 \%$ of surveyed UK clinicians felt that language barriers were an important factor in their decision to treat metastatic breast cancer with palliative chemotherapy. ${ }^{22}$

\section{Hospital/physician/insurance characteristics}

Four studies discussed differences in hospital, physician, or insurance status and their effect on the percentage of patients treated with chemotherapy ${ }^{19,23,24,28}$ (Table 2).

\section{Insurance status}

Two studies reported on insurance status. ${ }^{12-24}$ Liu and colleagues compared the proportion of women enrolled in the Women's Health Network (WHN) - a National Breast and Cervical Cancer Early Detection Program for uninsured, lower income women - who were treated with chemotherapy to the treatment of all other breast cancer cases (not limited to metastatic disease) reported to the Massachusetts Cancer Registry (MCR). ${ }^{24}$ They found that similar proportions of women in the WHN and the MCR received chemotherapy (35.4\% and $37.2 \%$, respectively), with no statistically

Table 2 Studies related to the role of hospital/physician/insurance characteristics in treatment decision making for breast cancer

\begin{tabular}{|c|c|c|c|}
\hline Reference & $\begin{array}{l}\text { Number of subjects } \\
\text { in study }\end{array}$ & $\begin{array}{l}\text { Percent of patients } \\
\text { receiving chemotherapy }\end{array}$ & Comment \\
\hline \multicolumn{4}{|c|}{ Insurance status } \\
\hline \multirow[t]{2}{*}{ Liu et $\mathrm{a}^{24}$} & $W H N: n=331$ (lower income) & Uninsured: 35.4 & Study included stages I-IV \\
\hline & Other in MA state: $n=13,372$ & Insured: 37.2 & $\begin{array}{l}\text { Numbers also reported under } \\
\text { SES/Income. } \\
\text { Reported } P=0.2\end{array}$ \\
\hline \multicolumn{4}{|c|}{ Medicare reimbursement rate } \\
\hline Jacobson et $\mathrm{al}^{23}$ & $\mathrm{n}=2,246$ & $\begin{array}{l}\text { By Medicare reimbursement index: } \\
\text { Average: } 25 \\
\text { Plus I standard deviation: } 26 . \mid\end{array}$ & Study included only stage IV \\
\hline \multicolumn{4}{|c|}{ Type of physician } \\
\hline Freyer et al ${ }^{19}$ & $\begin{array}{l}n=1,009 \\
-65-74: n=500 \\
-\geq 75: n=509\end{array}$ & - & $\begin{array}{l}\text { Study included stage IV only } \\
\text { Treatment chosen by a single } \\
\text { physician } 65-74 \text { years: } 30 \% \\
\geq 75 \text { years: } 43 \% \\
\text { Percentage of physician type } \\
\text { participating in therapeutic decision } \\
\text { (65-74 year age group, } \\
\geq 75 \text { year age group): } \\
\text { Medical oncologists: } 52 \%, 46 \% \\
\text { Radiotherapists: } 34 \%, 32 \% \\
\text { Surgeons: } 22 \%, 14 \% \\
\text { Gynecologists: } 18 \%, 14 \% \\
\text { General practitioners: } 4 \%, 4 \% \\
\text { Gerontologists: } 2 \%, 0 \%\end{array}$ \\
\hline \multicolumn{4}{|c|}{ Type of practice } \\
\hline Peele et $\mathrm{a}^{28}$ & $\mathrm{n}=386$ & $\begin{array}{l}\text { Patients treated at university-based } \\
\text { clinics were more likely to choose } \\
\text { chemotherapy treatment }\end{array}$ & $\begin{array}{l}\text { Study included stages I-IV } \\
\text { Reported } P<0.0 \text { I }\end{array}$ \\
\hline
\end{tabular}

Abbreviations: OR, odds ratio; NR, not reported;WHN,Women's Health Network; SES, socioeconomic status; MA, Massachusetts. 
significant differences; however, the very existence of the WHN likely increased the treatment percentages for uninsured women, indicating that this study does not preclude the role of insurance status in determining the rate of women receiving chemotherapy. In their qualitative study of the use of adjuvant therapies, including chemotherapy, in women with all stages of breast cancer in aggregate, Ashing-Giwa and colleagues supported the suggestion that uninsured individuals are less likely to seek medical care. ${ }^{12}$

\section{Medicare reimbursement rates}

In the only study identified in this category, Jacobson and colleagues found that the index of excess Medicare reimbursement had a minimal effect on the overall rate of chemotherapy treatment in cases with metastatic breast cancer, but did find that more generously reimbursed providers were more likely to choose more expensive chemotherapy regimens. ${ }^{23}$

\section{Physician type}

In a prospective survey of French specialists, including oncologists, radiotherapists, gynecologists, and internists, 1,009 patients with metastatic breast cancer aged 65 to 74 years and greater than 75 years old were evaluated. ${ }^{19}$ Results indicated that physician type played a role in treatment decision-making, with treatment chosen by a single physician - rather than in consultation - in 30\% of cases in the younger age group and in $43 \%$ of patients in the older group. Freyer and colleagues noted that geriatricians were involved in only $2 \%$ of treatment discussions in the older patients. ${ }^{19}$ This difference was proposed as a possible factor underlying the observed substandard treatment of older women with breast cancer.

\section{Type of practice}

Peele et al reported that women attending university-based practices were significantly more likely $(P<0.01)$ to choose adjuvant therapy, ${ }^{28}$ including chemotherapy, hormone therapy, and combination therapy. No other studies were identified that discussed practice type.

\section{Clinical characteristics}

Tumor characteristics and disease severity were the most frequently discussed clinical factors, considered in five of the seven studies identified in this category ${ }^{17,18,20,22,28}$ (Table 3). The patient's general health and co-morbidities were mentioned in four studies, ${ }^{14,18,19,22}$ and previous cancer treatments were mentioned in two studies. ${ }^{18,22}$ Three studies in this category were specific to metastatic breast cancer. ${ }^{18,19,22}$

\section{Tumor characteristics/disease severity}

Studies have demonstrated that chemotherapy is the preferred treatment in achieving pathologically complete remission in cases that are ER- and/or PR-negative, ${ }^{36}$ while hormonal and endocrine therapies may be more effective in the treatment of hormone receptor-positive disease. ${ }^{37}$ Accordingly, general clinical reviews indicated that chemotherapy should be used as the initial treatment in cases that are hormone receptor-negative ${ }^{37}$ and as treatment for ER/PR-positive advanced breast cancer that is refractory to hormonal therapy. ${ }^{38}$ The results of two analyses of the SEER-Medicare linked database may reflect these recommendations. In Du and Goodwin, ${ }^{17}$ patients with ER-negative disease (and positive lymph node status) were $425 \%$ more likely to receive chemotherapy than those with ER-positive disease. In another publication by $\mathrm{Du}$ and Goodwin, ${ }^{18}$ the overall proportion of breast cancer patients receiving chemotherapy was $69.9 \%$ and $48.4 \%$ for women with nodepositive/ER-negative tumors (age groups 65-69 and older than 65 years, respectively), while only $4.8 \%$ and $2.9 \%$ of women with node-negative/ER-positive disease received chemotherapy (age groups 65-69 and older than 65 years, respectively); however, neither study was specific to metastatic breast cancer for this particular factor.

Women with more severe disease (defined as having larger tumors, hormone-receptive negative disease, and node-positive disease) were more likely to undergo chemotherapy, ${ }^{17,18,20,28}$ especially when thoroughly informed about their treatment options through a decision aid, compared to a control pamphlet, in one trial $(P=0.04) .{ }^{28}$ The clinical characteristics most frequently cited as being important in clinicians' decisions to recommend palliative chemotherapy were the pace of disease progression (89.7\%) and site of metastases (79.3\%), with tumor histologic type/grade cited less frequently as important to the decision-making process (24.1\%). Other factors noted by more than half the clinicians as important included symptoms other than pain, concurrent medical conditions, site of metastases, toxicity with previous chemotherapy, pain, patient's wishes, frailty, age, and social support. ${ }^{22}$

\section{General health/co-morbidities}

The subjective determination of the patient's general health status was the most important criterion reported by clinicians for treatment with weaker doses of chemotherapy in a French prospective study of metastatic breast cancer cases. ${ }^{19}$ Performance status of the patient was one of the most frequently cited influential factors 
Table 3 Studies related to the role of clinical characteristics in treatment decision making for breast cancer

\begin{tabular}{|c|c|c|c|c|}
\hline Reference & $\begin{array}{l}\text { Number of subjects } \\
\text { in study }\end{array}$ & $\begin{array}{l}\text { Percent of patients } \\
\text { receiving chemotherapy }\end{array}$ & Odds ratio & Comment \\
\hline \multicolumn{5}{|c|}{ Tumor characteristics/disease severity } \\
\hline Du and Goodwin ${ }^{17}$ & $\begin{array}{l}n=10,604 \\
- \text { Node+/ER+: } n=1,741 \\
- \text { Node+/ER-: } n=335 \\
\text { - Node+/ER?: } n=418 \\
\text { - Node-/ER+: } n=3,879 \\
\text { - Node-/ER-: } n=689 \\
\text { - Node-/ER?: } n=1,319 \\
\text { - Node unexamined: } n=2,223\end{array}$ & $\begin{array}{l}\text { Node positive, } \\
\text { ER negative: } \\
65-69 \text { years: } 69.9 \\
65+\text { years: } 48.4 \\
\text { Node negative, } \\
\text { ER positive: } \\
65-69 \text { years: } 4.8 \\
65+\text { years: } 2.9 \\
-\end{array}$ & $\begin{array}{l}\text { Odds of receiving } \\
\text { chemotherapy relative to } \\
\text { a tumor size }<1.0 \mathrm{~cm} \text { : } \\
\text { I.0-<2.0 cm: I.90 } \\
(95 \% \mathrm{Cl}: \text { I.43-2.5I) } \\
2.0-<3.0 \mathrm{~cm}: 1.69 \\
(95 \% \mathrm{Cl}: 1.24-2.32) \\
3.0-<4.0 \mathrm{~cm}: 2.26 \\
(95 \% \mathrm{Cl}: 1.59-3.22) \\
4.0+\mathrm{cm}: 2.16 \\
(95 \% \mathrm{Cl}: 1.52-3.06) \\
\text { Unknown: } 2.98 \\
(95 \% \mathrm{Cl}: 1.99-4.50)\end{array}$ & Study included stages I-IV \\
\hline Du and Goodwin ${ }^{18}$ & $\mathrm{n}=35,060$ & - & $\begin{array}{l}\text { Lymph node positive } \\
\text { and ER negative relative } \\
\text { to lymph node positive } \\
\text { and ER positive: } \\
4.25 \text { ( } 95 \% \mathrm{Cl}: 2.69-4.89) \\
\text { Large relative to } \\
\text { small tumor size: } \\
\text { I.94 ( } 95 \% \mathrm{Cl} \text { : I.6I-2.34) } \\
\text { Higher relative to } \\
\text { lower stage: } \\
5.6 \mathrm{I}(95 \% \mathrm{Cl}: 4.54-6.92)\end{array}$ & Study included stages I-IV \\
\hline Golledge et $\mathrm{al}^{20}$ & $n=784$ & $\begin{array}{l}\text { Lymph node positive: } 25 \\
\text { Lymph node negative: } 9\end{array}$ & - & Study included stages I-IV \\
\hline Grunfeld et al ${ }^{22}$ & $\mathrm{n}=30$ oncologists & - & - & $\begin{array}{l}\text { Surveyed for stage IV } \\
\text { treatment only } \\
\text { Authors report that } 27.6 \% \text { of } \\
\text { clinicians rated ER/PR } \\
\text { status as quite or very } \\
\text { important in decision to } \\
\text { treat with palliative } \\
\text { chemotherapy }\end{array}$ \\
\hline Peele et $\mathrm{a}^{28}$ & $\mathrm{n}=386$ & $\begin{array}{l}\text { Patients with more } \\
\text { severe disease were } \\
\text { more likely to choose } \\
\text { chemotherapy treatment }\end{array}$ & - & $\begin{array}{l}\text { Study included stages I-IV } \\
\text { Reported } P \text {-value }<0.000 \text { I }\end{array}$ \\
\hline & & $\begin{array}{l}\text { Low severity with a } \\
\text { decision aid: } 58.3 \\
\text { Low severity with a } \\
\text { control pamphlet: } 86.8 \\
\text { High severity with a } \\
\text { decision aid: } 98.6 \\
\text { High severity with a } \\
\text { control pamphlet: } 92.3\end{array}$ & - & $\begin{array}{l}\text { Study included stages I-IV } \\
\text { Reported } P \text {-values } 0.003 \text { for } \\
\text { low severity and } 0.04 \\
\text { for high severity }\end{array}$ \\
\hline
\end{tabular}


Table 3 (Continued)

\begin{tabular}{|c|c|c|c|c|}
\hline Reference & $\begin{array}{l}\text { Number of subjects } \\
\text { in study }\end{array}$ & $\begin{array}{l}\text { Percent of patients } \\
\text { receiving chemotherapy }\end{array}$ & Odds ratio & Comment \\
\hline \multicolumn{5}{|c|}{ Patient health/comorbidities } \\
\hline Caban et al ${ }^{14}$ & $n=234$ & $\begin{array}{l}\text { Patients with disability: } 13 \% \\
\text { Patients without } \\
\text { disability: } 29 \%\end{array}$ & - & $\begin{array}{l}\text { Study includes stages I-IV } \\
\text { Reported } P \text {-value } 0.180 \\
\text { Disabilities included those } \\
\text { that limited the patient's } \\
\text { mobility and ability to lie flat } \\
\text { and limitations of joint } \\
\text { mobility that prevented } \\
\text { abduction of the shoulder }\end{array}$ \\
\hline $\begin{array}{l}\text { Du and } \\
\text { Goodwin }{ }^{17}\end{array}$ & $\begin{array}{l}\mathrm{n}=10,604 \\
\text { - no comorbidity } \\
\quad \text { claims: } \mathrm{n}=312 \\
-0 \text { comorbidities: } \mathrm{n}=8,160 \\
-1 \text { comorbidity: } \mathrm{n}=815 \\
-2 \text { comorbidities: } \mathrm{n}=372 \\
-3+\text { comorbidities: } \mathrm{n}=945\end{array}$ & - & $\begin{array}{l}\text { Odds of receiving } \\
\text { chemotherapy relative to a } \\
\text { comorbidity index of } 0: \\
\text { No comorbidity claims: } \\
0.68 \text { ( } 95 \% \text { Cl: } 0.4 \text { I-I.I2) } \\
\text { Comorbidity index I: } 0.80 \\
(95 \% \text { Cl: } 0.59-1.07) \\
\text { Comorbidity index } 2: 0.46 \\
(95 \% \text { Cl: } 0.27-0.76) \\
\text { Comorbidity index } 3+: 0.94 \\
(95 \% \mathrm{Cl}: 0.77-1.16)\end{array}$ & Study includes stages I-IV \\
\hline Freyer et al ${ }^{19}$ & $\mathrm{n}=1,009$ & - & - & $\begin{array}{l}\text { Study includes stage IV only } \\
\text { Physicians indicated that } \\
\text { subjective determination of } \\
\text { general health status was the } \\
\text { most important criterion for } \\
\text { treatment with weaker doses } \\
\text { of chemotherapy }\end{array}$ \\
\hline Grunfeld et al22 & $\mathrm{n}=30$ oncologists & - & - & $\begin{array}{l}\text { Surveyed for stage IV } \\
\text { treatment only } \\
\text { Percent of clinicians rating } \\
\text { factor as quite or very } \\
\text { important in decision to treat } \\
\text { with palliative chemotherapy: } \\
\text { Performance status: } 96.6 \% \\
\text { Concurrent medical condi- } \\
\text { tions: } 82.8 \% \text { Frailty: } 93.1 \%\end{array}$ \\
\hline \multicolumn{5}{|c|}{ Previous treatment } \\
\hline Du and Goodwin ${ }^{17}$ & $\begin{array}{l}n=10,604 \\
- \text { No surgery: } n=29 \mid \\
\text { - BCS only: } n=1,446 \\
\text { - BCS and RT: } n=2,236 \\
\text { - Mastectomy only: } n=6,|3| \\
\text { - Mastectomy and RT: } n=500\end{array}$ & $\begin{array}{l}\text { No surgery: } 27.2 \\
\text { BCS only: } 37.5 \\
\text { BCS and RT: } 23.1 \\
\text { Mastectomy only: } 19.4 \\
\text { Mastectomy and } \\
\text { radiotherapy: } 30.2\end{array}$ & 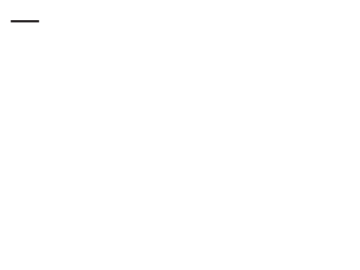 & $\begin{array}{l}\text { Information is specific to } \\
\text { stage IV }\end{array}$ \\
\hline & & - & $\begin{array}{l}\text { Odds of receiving } \\
\text { chemotherapy relative to } \\
\text { no surgery as previous } \\
\text { treatment: } \\
\text { BCS only: } 0.95 \\
(95 \% \mathrm{Cl}: 0.63-1.45) \\
\mathrm{BCS} \text { and radiotherapy: } 0.63 \\
(95 \% \mathrm{Cl}: 0.4 \mathrm{I}-0.96) \\
\text { Mastectomy only: } 0.83 \\
(95 \% \mathrm{Cl}: 0.55-1.25) \\
\text { Mastectomy and radiotherapy: } \\
0.92 \text { ( } 95 \% \mathrm{Cl}: 0.60-1.43)\end{array}$ & $\begin{array}{l}\text { Information includes stages } \\
\text { I-IV }\end{array}$ \\
\hline
\end{tabular}

(Continued) 
Table 3 (Continued)

\begin{tabular}{|c|c|c|c|c|}
\hline Reference & $\begin{array}{l}\text { Number of subjects } \\
\text { in study }\end{array}$ & $\begin{array}{l}\text { Percent of patients } \\
\text { receiving chemotherapy }\end{array}$ & Odds ratio & Comment \\
\hline Grunfeld et $\mathrm{al}^{22}$ & $\mathrm{n}=30$ oncologists & - & - & $\begin{array}{l}\text { Surveyed stage IV treatment } \\
\text { only. Percent of clinicians } \\
\text { rating factor as quite or very } \\
\text { important in decision to treat } \\
\text { with palliative chemotherapy: } \\
\text { Previous response to } \\
\text { chemo: } 86.2 \% \\
\text { Toxicity w/previous che- } \\
\text { motherapy: } 79.3 \% \text { Previ- } \\
\text { ous response to hormone } \\
\text { therapy: } 37.9 \%\end{array}$ \\
\hline
\end{tabular}

Abbreviations: OR, odds ratio; $\mathrm{Cl}$, confidence interval; NR, not reported; BCS, breast-conserving surgery; ER, estrogen-receptor; PR, progesterone-receptor; RT, radiotherapy

(96.6\%) in recommending palliative chemotherapy among UK clinicians. ${ }^{22}$ Other factors relating to patient health were also considered important, with $93.1 \%$ and $82.8 \%$, respectively, agreeing that patient frailty and concurrent medical conditions were important. One study of breast cancer cases reported a statistically significantly lower probability of receiving chemotherapy for women with a co-morbidity index of two, compared to those with a co-morbidity index of $0(\mathrm{OR}=0.46$; $95 \% \mathrm{CI}: 0.27-0.76)$, although this inverse relationship was not statistically significant among patients with a co-morbidity index of 3 or greater. ${ }^{18}$ Caban and colleagues did not find a significant difference in the rate of neoadjuvant chemotherapy treatment based on patient disabilities that limited mobility. ${ }^{14}$ While effects of specific co-morbidities may vary, the current studies indicate that overall health is an important factor in predicting receipt of chemotherapy for breast cancer.

\section{Previous cancer treatments}

$\mathrm{Du}$ and Goodwin provide data on the proportion of women with metastatic breast cancer who received chemotherapy according to their previous breast cancer treatments. ${ }^{18}$ The rates ranged from $19.4 \%$ (in those previously treated with mastectomy only) to $30.2 \%$ (in those previously treated with mastectomy and radiotherapy), although the authors did not report whether the difference was significant and did not indicate any clear trend, making it difficult to draw any conclusions from these data. Grunfeld and colleagues ${ }^{22}$ cited "toxicity with previous chemotherapy" and "previous response to chemotherapy" as important factors in the decision to treat metastatic breast cancer with palliative chemotherapy by $79.3 \%$ and $86.2 \%$ of surveyed clinicians, respectively.

\section{Psychosocial characteristics}

Psychosocial characteristics studied in relation to receipt of chemotherapy for breast cancer included the presence of social partners or support, ${ }^{18,22,27}$ mental health, ${ }^{21,22}$ and the attempt to minimize the psychosocial impact of cancer on social, work, and family lives ${ }^{13}$ (Table 4).

\section{Social support/partners}

Two studies provided numerical data regarding the impact of a spouse or significant other on the receipt of chemotherapy treatment, ${ }^{18,27}$ one of which provided data specific to metastatic breast cancer. ${ }^{18}$ Osborne and colleagues and Du and Goodwin reported that married women were more likely to receive chemotherapy than unmarried women (married $=$ $12.3 \%$ versus unmarried $=9.1 \% ;{ }^{27}$ married $=37.4 \%$ versus unmarried $=20.7 \%^{18}$ ). One study suggested that unmarried women might receive chemotherapy less often due to patients' personal concerns over postoperative assistance and transportation or the amount of out-of-pocket expense for treatment, or due to a doctor's decision not to discuss such treatment options because of these assumptions. ${ }^{27}$ Of British clinicians surveyed, $51.7 \%$ reported that the patient's social support was an important factor in their decision to give palliative chemotherapy to women with metastatic breast cancer. ${ }^{22}$

\section{Mental health}

In an analysis of the SEER-Medicare linked database, the authors reported that, among women whose breast cancer was stage IV at diagnosis, breast cancer cases with a prior diagnosis of depression were less likely to receive chemotherapy than were women without a prior diagnosis of depression $(34.1 \%$ [nondepressed] versus $18.6 \%$ [depressed]; $P<0.001) .{ }^{21} \mathrm{In}$ a British survey, $44.8 \%$ of clinicians reported that a patient's anxiety and depression were "quite important" or "very 
Table 4 Studies related to the role of psychosocial characteristics in treatment decision making for breast cancer

\begin{tabular}{|c|c|c|c|c|}
\hline Reference & $\begin{array}{l}\text { Number of subjects } \\
\text { in study }\end{array}$ & $\begin{array}{l}\text { Percent of patients } \\
\text { receiving chemotherapy }\end{array}$ & Odds ratio & Comment \\
\hline \multicolumn{5}{|c|}{ Social partner/social support } \\
\hline \multirow[t]{2}{*}{ Du and Goodwin ${ }^{17}$} & $\begin{array}{l}n=10,604 \\
\text { - Married: } n=4,368 \\
\text { - Unmarried: } n=5,937 \\
\text { - Unknown: } n=299\end{array}$ & $\begin{array}{l}\text { Married: } 37.4 \\
\text { Unmarried: } 20.7 \\
\text { Unknown: } 18.8\end{array}$ & - & $\begin{array}{l}\text { Information is specific } \\
\text { to stage IV disease }\end{array}$ \\
\hline & & - & $\begin{array}{l}\text { Odds of receiving } \\
\text { chemotherapy } \\
\text { relative to married } \\
\text { patients: } \\
\text { Unmarried: } 0.8 \mathrm{I} \\
\text { (95\% Cl: } 0.70-0.94) \\
\text { Unknown: } 0.68 \\
(95 \% \mathrm{Cl}: 0.42-1.10)\end{array}$ & $\begin{array}{l}\text { Information includes } \\
\text { stages I-IV }\end{array}$ \\
\hline Grunfeld et $\mathrm{al}^{22}$ & $\mathrm{n}=30$ oncologists & - & - & $\begin{array}{l}\text { Surveyed for stage IV } \\
\text { treatment only. } \\
\text { Authors report that } 51.7 \% \text { of } \\
\text { clinicians rated social support } \\
\text { as quite or very important in } \\
\text { the decision to treat with } \\
\text { palliative chemotherapy }\end{array}$ \\
\hline Osborne et $\mathrm{al}^{27}$ & $\begin{array}{l}n=32,268 \\
\text { - Married: } n=\mid 4,247 \\
\text { - Unmarried: } n=18,02 \mid\end{array}$ & $\begin{array}{l}\text { Married: } 12.3 \\
\text { Unmarried: } 9.1\end{array}$ & - & $\begin{array}{l}\text { Study included stages I-IV } \\
\text { Reported } P \text {-value }<0.00 \mathrm{I}\end{array}$ \\
\hline \multicolumn{5}{|l|}{ Mental health } \\
\hline Goodwin et $\mathrm{al}^{21}$ & $\begin{array}{l}\mathrm{n}=24,696 \\
\text { - Depressed: } \mathrm{n}=1,84 \mathrm{I} \\
\text { - Nondepressed: } \mathrm{n}=22,855\end{array}$ & $\begin{array}{l}\text { Depressed: } 18.6 \\
\text { Nondepressed: } 34.1\end{array}$ & - & $\begin{array}{l}\text { Study included only } \\
\text { stage IV cases } \\
\text { Reported } p \text {-value } 0.0142\end{array}$ \\
\hline Grunfeld et $\mathrm{a}^{22}$ & $\mathrm{n}=30$ oncologists & - & - & $\begin{array}{l}\text { Surveyed for stage IV } \\
\text { treatment only. Percent of } \\
\text { clinicians rating factor as quite } \\
\text { or very important in decision } \\
\text { to treat with palliative chemo- } \\
\text { therapy: Anxiety: } 44.8 \% \\
\text { Depression: } 44.8 \% \\
\text { Pre-morbid } \\
\text { personality: } 27.6 \%\end{array}$ \\
\hline \multicolumn{5}{|c|}{ Psychosocial impact minimization } \\
\hline Butow et al ${ }^{13}$ & $\begin{array}{l}\mathrm{n}=99 \\
\text { (minimizers defined } \\
\text { as those who scored } \\
\text { above median, nonminimizers } \\
\text { were those who scored at } \\
\text { or below median) }\end{array}$ & $\begin{array}{l}\text { Patient attempted to } \\
\text { minimize impact on } \\
\text { social, work, and family } \\
\text { life, percent that received } \\
\text { chemotherapy: } \\
\text { Yes: } 22.0 \\
\text { No: } 55.0\end{array}$ & - & $\begin{array}{l}\text { Study included only stage IV } \\
\text { Reported } P \text {-value }<0.00 \text { I }\end{array}$ \\
\hline \multicolumn{5}{|c|}{ Patient/family wishes } \\
\hline Grunfeld et al ${ }^{22}$ & $\mathrm{n}=30$ oncologists & - & - & $\begin{array}{l}\text { Surveyed for stage IV } \\
\text { treatment only } \\
\text { Percent of clinicians rating fac- } \\
\text { tor as quite or very important } \\
\text { in decision to treat with } \\
\text { palliative chemotherapy: } \\
\text { Patient's wishes: } 96.6 \% \\
\text { Patient's family's wishes: } 37.9 \%\end{array}$ \\
\hline
\end{tabular}

Abbreviations: $\mathrm{OR}$, odds ratio; $\mathrm{Cl}$, confidence interval; $\mathrm{NR}$, not reported. 
important" in their decision to give palliative chemotherapy to patients with metastatic breast cancer, although only $27.7 \%$ felt that the patient's pre-morbid personality was important. ${ }^{22}$

\section{Psychosocial impact minimization}

Butow and colleagues reported that Australian women with metastatic breast cancer who were attempting to minimize the impact of their disease on their social, work, and family life (termed "minimizers") were significantly less likely to receive chemotherapy than those who were not minimizing the impact of the disease ("nonminimizers") ${ }^{13}$. Specifically, $55 \%$ of nonminimizers received chemotherapy, a statistically significant difference compared to minimizers $(P<0.001)$.

\section{Patient/family wishes}

Grunfeld and colleagues reported that $96.6 \%$ of British clinicians considered the desire of the patient to continue treatment an important factor in their decision to recommend palliative treatment for metastatic breast cancer. ${ }^{22}$ The wishes of the patient's family were reported to be influential to a lower proportion of clinicians $(37.9 \%){ }^{22}$

\section{Discussion}

In this review of literature describing factors associated with receipt of chemotherapy among women with breast cancer, we found that women receiving chemotherapy tended to be younger, healthier, more frequently Caucasian, and of higher educational status, and had clinical characteristics of more severe disease, such as ER/PR-negative tumors. There was some evidence that the type of physician and attending a university-based facility were related to more frequent use of chemotherapy. Women with emotional/mental health issues and less social support were less likely to receive chemotherapy, although these observations need to be replicated in additional studies to determine whether they constitute consistent trends. There was less evidence that factors such as income, insurance characteristics, or Medicare reimbursement rates had substantive influence on whether chemotherapy was used, with sometimes only a single study discussing these factors.

Only six of the 19 studies focused on women with metastatic breast cancer, with the remaining studies analyzing cases of stage IV breast cancer in combination with all other stages of breast cancer. Typically, only a small percentage of the aggregated cases had metastatic disease. As noted earlier, the emphasis on palliative, rather than curative, treatment for those with metastatic disease would most likely influence differences in treatment patterns. However, a qualitative review of these studies reporting specifically on metastatic breast cancer compared to those evaluating all cases in aggregate revealed no striking differences in factors affecting treatment receipt across stage, suggesting that the factors listed above are likely important for women with both early- and late-stage disease.

The patterns of chemotherapy use observed in this review appear to largely reflect a few general underlying influences. The lack of chemotherapy for older women is important, because breast cancer incidence and mortality rates peak in the elderly, ${ }^{2}$ and the population of elderly women in the US is growing rapidly. ${ }^{39}$ The conservative use of chemotherapy in the elderly has been reported consistently for several other cancer types. ${ }^{40-43}$ Older age and multimorbidity are often intertwined as co-morbidities increase with advancing age, which may limit treatment options. ${ }^{44,45}$ The less frequent use among older women and women with lower general health status and higher numbers of co-morbidities may also reflect lack of evidence of efficacy, because these women are typically underrepresented in clinical trials. It is also possible that, because the proportion of ER-positive tumors increases with age, ${ }^{46}$ the less frequent use of chemotherapy among older women reflects the shift from cytotoxic regimens to hormonal therapies, as per current clinical guidelines for treatment of hormone receptor-positive tumors. ${ }^{6,44}$

The less frequent use of chemotherapy among ethnic/ racial minorities, and women of lower educational attainment, is consistent with the results of other studies of health disparities in cancer outcomes and treatment, as well as other diseases, and most likely reflects limitations in access to care and unawareness of treatment options..$^{35,47}$ The decreased chemotherapy use among women with emotional and mental health issues may reflect the recognition on the part of the treating physician, and possibly the patient herself, of the trade-offs between quantity of life gained and quality of life lost at this juncture. ${ }^{7}$

There are a few important limitations to consider when interpreting these results. In addition to the relative paucity of studies examining factors that affect receipt of chemotherapy, with only 19 studies identified since 2000, no study attempted to thoroughly dissect the many potential factors that may be involved. Most studies considered only one or two factors, and as such, were unable to adjust for correlations and potentially confounding effects, possibly creating spurious relationships and/or obscuring true ones. This could have considerable effects on conclusions derived from observational and other epidemiologic studies, as well as 
outcomes research. It is also likely that several other factors not reported in these papers may play an important role in the decision to treat metastatic breast cancer with chemotherapy or discussed factors that did not fall into the four categories of interest. Therefore, comprehensive studies examining these interrelated factors are needed to better understand the factors associated with receiving chemotherapy for metastatic breast cancer. Finally, because the study designs, the populations studied, and the measures of association varied so much across studies, summary measures could not be calculated, and results reflect a more qualitative than quantitative review of the literature.

Studying the patient, insurance/provider, and psychosocial factors associated with receipt of chemotherapy among breast cancer patients can provide a real-world view of usage patterns of treatment in clinical practice. While it is apparent that a combination of clinical guidelines, possible social disparities in health care, and personal decision-making styles and beliefs among patients and their providers play a role in chemotherapy use, the current body of literature does not allow quantitative comparisons and assessments of the relative contributions of each selective factor. This review highlights the paucity of quantitative literature available with which to study the impact of these factors, both individually and as interrelated variables that inevitably impact each other. Future studies examining these patterns can aid patients and care providers when interpreting the clinical literature and making decisions about best course of treatment. Differential patterns of care can also provide guidance to policy makers when developing programs and interventions to reduce disparities in health care access.

\section{Acknowledgments/disclosures}

Funded by Amgen, Inc. Dr O'Malley is an employee of Amgen, Inc. Drs Morimoto and Mowat and Ms Coalson are or were employees of Exponent, Inc. at the time of writing. The authors report no conflicts or competing financial interests in this work.

\section{References}

1. US National Institutes of Health; National Cancer Institute. Office of Budget and Finance. Available from: http://obf.cancer.gov/. Accessed July 9, 2009.

2. American Cancer Society. Cancer Facts and Figures. Atlanta, GA: American Cancer Society; 2009.

3. Ries LAG, Melbert D, Krapcho M, et al. SEER Cancer Statistics Review, 1975-2005. Bethseda, MD: National Cancer Institute; 2008.

4. Dawood S, Broglio K, Esteva FJ, et al. Defining prognosis for women with breast cancer and CNS metastases by HER2 status. Ann Oncol. 2008;19(7):1242-1248.

5. Weigelt B, Peterse JL, van 't Veer LJ. Breast cancer metastasis: markers and models. Nat Rev Cancer. 2005;5(8):591-602.
6. Network NCC, editor. Breast Cancer Treatment Guidelines for Patients. Vol Version IX. Atlanta, GA: American Cancer Society; 2007.

7. Cardoso F, Di LA, Lohrisch C, Bernard C, Ferreira F, Piccart MJ. Second and subsequent lines of chemotherapy for metastatic breast cancer: what did we learn in the last two decades? Ann Oncol. 2002;13(2):197-207.

8. US Department of Health and Human Services; Health Resources and services Administration. Health Disparities Collaboratives (HDC). Available from: http://www.healthdisparities.net/hdc/html/home.aspx. Accessed June 25, 2008.

9. US Department of Health and Human Services. Healthy People 2010: Understanding and improving health. 2nd ed. Vol 2000-23-8. Washington, DC: US Government Printing Office; 2000.

10. National Institutes of Health. Strategic Research Plan to Reduce and Ultimately Eliminate Health Disparities, Fiscal Years 2002-2006. 2006. Available from: http://ncmnd.nih.gov/our_programs/strategic/. Accessed June 25, 2008.

11. Lisovicz N, Wynn T, Fouad M, Partridge EE. Cancer health disparities: what we have done. Am J Med Sci. 2008;335(4):254-259.

12. Ashing-Giwa KT, Padilla G, Tejero J, et al. Understanding the breast cancer experience of women: a qualitative study of African American, Asian American, Latina and Caucasian cancer survivors. Psychooncology. 2004;13(6):408-428.

13. Butow PN, Coates AS, Dunn SM. Psychosocial predictors of survival: metastatic breast cancer. Ann Oncol. 2000;11(4):469-474.

14. Caban ME, Nosek MA, Graves D, Esteva FJ, McNeese M. Breast carcinoma treatment received by women with disabilities compared with women without disabilities. Cancer. 2002;94(5):13911396.

15. Diab SG, Elledge RM, Clark GM. Tumor characteristics and clinical outcome of elderly women with breast cancer. J Natl Cancer Inst. 2000;92(7):550-556.

16. Downing A, Prakash K, Gilthorpe MS, Mikeljevic JS, Forman D. Socioeconomic background in relation to stage at diagnosis, treatment and survival in women with breast cancer. Br J Cancer. 2007; 96(5):836-840.

17. Du X, Goodwin JS. Increase of chemotherapy use in older women with breast carcinoma from 1991 to 1996. Cancer. 2001;92(4): 730-737.

18. Du X, Goodwin JS. Patterns of use of chemotherapy for breast cancer in older women: findings from Medicare claims data. J Clin Oncol. 2001;19(5):1455-1461.

19. Freyer G, Braud AC, Chaibi P, et al. Dealing with metastatic breast cancer in elderly women: results from a French study on a large cohort carried out by the 'Observatory on Elderly Patients'. Ann Oncol. 2006;17(2):211-216.

20. Golledge J, Wiggins JE, Callam MJ. Age-related variation in the treatment and outcomes of patients with breast carcinoma. Cancer. 2000;88(2):369-374.

21. Goodwin JS, Zhang DD, Ostir GV. Effect of depression on diagnosis, treatment, and survival of older women with breast cancer. JAm Geriatr Soc. 2004;52(1):106-111.

22. Grunfeld EA, Ramirez AJ, Maher EJ, et al. Chemotherapy for advanced breast cancer: what influences oncologists' decision-making? Br J Cancer. 2001;84(9):1172-1178.

23. Jacobson M, O'Malley AJ, Earle CC, Pakes J, Gaccione P, Newhouse JP. Does reimbursement influence chemotherapy treatment for cancer patients? Health Aff (Millwood). 2006;25(2):437-443.

24. Liu MJ, Hawk H, Gershman ST, et al. The effects of a National Breast and Cervical Cancer Early Detection Program on social disparities in breast cancer diagnosis and treatment in Massachusetts. Cancer Causes Control. 2005;16(1):27-33.

25. Maloney N, Koch M, Erb D, et al. Impact of race on breast cancer in lower socioeconomic status women. Breast J. 2006;12(1):58-62.

26. Mitchell J, Lannin DR, Mathews HF, Swanson MS. Religious beliefs and breast cancer screening. $J$ Womens Health (Larchmt). 2002;11(10):907-915. 
27. Osborne C, Ostir GV, Du X, Peek MK, Goodwin JS. The influence of marital status on the stage at diagnosis, treatment, and survival of older women with breast cancer. Breast Cancer Res Treat. 2005;93(1):41-47.

28. Peele PB, Siminoff LA, Xu Y, Ravdin PM. Decreased use of adjuvant breast cancer therapy in a randomized controlled trial of a decision aid with individualized risk information. Med Decis Making. 2005;25(3):301-307.

29. Shavers VL, Harlan LC, Stevens JL. Racial/ethnic variation in clinical presentation, treatment, and survival among breast cancer patients under age 35. Cancer. 2003;97(1):134-147.

30. Wyld L, Garg DK, Kumar ID, Brown H, Reed MW. Stage and treatment variation with age in postmenopausal women with breast cancer: compliance with guidelines. Br J Cancer. 2004;90(8):1486-1491.

31. Gajdos C, Tartter PI, Bleiweiss IJ, Lopchinsky RA, Bernstein JL. The consequence of undertreating breast cancer in the elderly. $\mathrm{J} \mathrm{Am} \mathrm{Coll}$ Surg. 2001;192(6):698-707.

32. Dunnwald LK, Rossing MA, Li CI. Hormone receptor status, tumor characteristics, and prognosis: a prospective cohort of breast cancer patients. Breast Cancer Res. 2007;9(1):R6.

33. Downey L, Livingston R, Stopeck A. Diagnosing and treating breast cancer in elderly women: a call for improved understanding. $J \mathrm{Am}$ Geriatr Soc. 2007;55(10):1636-1644.

34. Hutchins LF, Unger JM, Crowley JJ, Coltman CA Jr, Albain KS. Underrepresentation of patients 65 years of age or older in cancertreatment trials. N Engl J Med. 1999;341(27):2061-2067.

35. Kolb B, Wallace AM, Hill D, Royce M. Disparities in cancer care among racial and ethnic minorities. Oncology. 2006;20(10):1256-1261.

36. Colleoni M, Viale G, Zahrieh D, et al. Chemotherapy is more effective in patients with breast cancer not expressing steroid hormone receptors: a study of preoperative treatment. Clin Cancer Res. 2004;10(19): 6622-6628.

37. Orlando L, Colleoni M, Fedele P, et al. Management of advanced breast cancer. Ann Oncol. 2007;18(Suppl 6):vi74-76.
38. Mayer EL, Burstein HJ. Chemotherapy for metastatic breast cancer. Hematol Oncol Clin North Am. 2007;21(2):257-272.

39. He W, Sengupta M, Velkoff V, DeBarros KZ. 65+ in the United States: 2005. In: US Census Bureau CPR. Washington, DC: US Government Printing Office; 2005:6.

40. Ayanian JZ, Zaslavsky AM, Fuchs CS, et al. Use of adjuvant chemotherapy and radiation therapy for colorectal cancer in a population-based cohort. J Clin Oncol. 2003;21(7):1293-1300.

41. Cress RD, O'Malley CD, Leiserowitz GS, Campleman SL. Patterns of chemotherapy use for women with ovarian cancer: a population-based study. J Clin Oncol. 2003;21(8):1530-1535.

42. Janssen-Heijnen ML, Houterman S, Lemmens VE, Louwman MW, Maas HA, Coebergh JW. Prognostic impact of increasing age and co-morbidity in cancer patients: a population-based approach. Crit Rev Oncol Hematol. 2005;55(3):231-240.

43. Ramsey SD, Howlader N, Etzioni RD, Donato B. Chemotherapy use, outcomes, and costs for older persons with advanced nonsmall-cell lung cancer: evidence from surveillance, epidemiology and end results-Medicare. J Clin Oncol. 2004;22(24):4971-4978.

44. Giordano SH, Hortobagyi GN, Kau SW, Theriault RL, Bondy ML. Breast cancer treatment guidelines in older women. J Clin Oncol. 2005;23(4):783-791.

45. Yancik R, Wesley MN, Ries LA, Havlik RJ, Edwards BK, Yates JW. Effect of age and comorbidity in postmenopausal breast cancer patients aged 55 years and older. JAMA. 2001;285(7):885-892.

46. Anderson WF, Chu KC, Chatterjee N, Brawley O, Brinton LA. Tumor variants by hormone receptor expression in white patients with node-negative breast cancer from the surveillance, epidemiology, and end results database. J Clin Oncol. 2001;19(1):18-27.

47. Roux G, Dingley C, Lewis KL, Grubbs R. Health disparities in practice and research for aging women with cancer. $J$ Cult Divers. 2004;11(1):31-38.
International Journal of Women's Health

\section{Publish your work in this journal}

The International Journal of Women's Health is an international, peerreviewed open-access journal publishing original research, reports, reviews and commentaries on all aspects of women's healthcare including gynaecology, obstetrics, and breast cancer. Subject areas include: Chronic conditions (migraine headaches, arthritis, osteoporosis);

\section{Dovepress}

Endocrine and autoimmune syndromes; Sexual and reproductive health; Psychological and psychosocial conditions. The manuscript management system is completely online and includes a very quick and fair peer-review system. Visit http://www.dovepress.com/ testimonials.php to read real quotes from published authors. 